\title{
WYBRANE POGLĄDY KS. PROF. ANTONIEGO SZYMAŃSKIEGO NA PRAWO. UWAGI NA MARGINESIE NIEPUBLIKOWANEGO RĘKOPISU Z BIBLIOTEKI UNIWERSYTECKIEJ KUL
}

\section{WPROWADZENIE}

Poglądy naukowe ks. prof. Antoniego Szymańskiego doczekały się nielicznych opracowań ${ }^{1}$, choć staraniem J. Potrzeszcz w 2018 r. udało się wznowić wydane za jego życia dzieła ${ }^{2}$. Ogłoszone dotychczas prace skupiają się przede wszystkim na jego wizjach polityki społecznej oraz na koncepcjach odnoszących się do zagadnień społeczno-gospodarczych. W skromnym zbiorze publikacji poświęconych myśli lubelskiego uczonego próżno szukać jednak jakiejkolwiek syntezy jego wizji o charakterze filozoficznoprawnym $^{3}$.

Przywołane niżej wybrane poglądy ks. A. Szymańskiego zrekonstruowano na podstawie jego niepublikowanego rękopisu. Jest on przechowywany w Bibliotece Uniwersyteckiej Katolickiego Uniwersytetu Lubelskiego. Roboczo nadano mu tytuł „Prawo”4. Zapiski te stanowią dla prawnika

MGr PAtRYK KuPIS - Wydział Prawa i Administracji, Uniwersytet Szczeciński; adres do korespondencji: ul. Narutowicza 17A, 70-240 Szczecin, Polska; e-mail: patryk. kupis@usz.edu.pl; https://orcid.org/0000-0002-3044-3350

${ }^{1}$ Zob.: Kępa 2016; Pawlak 2011; Bogusz 1985, 279-94; Szczęsny 2005.

${ }^{2}$ Zob. Antoni Szymański. O sprawiedliwość społeczna. Wybór pism. Wyboru dokonała, wstępem i przypisami opatrzyła J. Potrzeszcz, Ośrodek Myśli Politycznej, Kraków 2018.

${ }^{3}$ Wybiórcze uwagi odnoszące się do relacji prawo-ekonomia zob. Gazda 1998, 41.

${ }^{4}$ Zob. BU KUL, Rkps 2277. 
nieocenione źródło wiadomości o poglądach lubelskiego uczonego. Zupełnie $\mathrm{w}$ innym świetle przedstawiają one intelektualną sylwetkę ich autora. Okazuje się bowiem, że ks. Szymański nie tylko posiadał dogłębną wiedzę prawniczą, znakomite przygotowanie teoretyczne, ale także udało mu się z nich zrobić znakomity użytek. W swej pracy był w stanie podjąć imponujące polemiki $\mathrm{z}$ przedstawicielami najważniejszych i najpopularniejszych ówcześnie prądów filozoficznoprawnych. Z badawczego punktu widzenia jest to źródło bezcenne, ponieważ jego analiza umożliwia nie tyle wzbogacenie biogramu uczonego o daty i fakty z jego życia ${ }^{5}$, ile $\mathrm{z}$ wielką dokładnością uzupełnić jego naukowe portfolio.

Nie jest znana dokładna data powstania badanego źródła. Wiele wskazuje na to, że spisano je w początkowym okresie II wojny światowej ${ }^{6}$. Przemawia za tym forma zapisków. Rękopis powstał na wtórnym materiale w postaci częściowo zadrukowanych kartek (zapisane zwartym pismem rozważania znajdują się np. na zaproszeniu na seminarium naukowe, starych ustawach czy dawnych notatkach). Całość ma charakter rzetelnie opracowanego skryptu. Mógł on zostać stworzony na użytek tajnych kompletów prowadzonych przez ks. prof. Szymańskiego lub w celu wykorzystania go po wznowieniu działalności lubelskiej wszechnicy (naturalnie pierwsze nie wyklucza drugiego).

\section{ANTONI SZYMAŃSKI - SZKIC BIOGRAFICZNY}

Ks. prof. A. Szymański urodził się 27 października 1881 r. w Praszce (dzisiejsze województwo opolskie). Po ukończeniu szkoły średniej i seminarium duchownego w Częstochowie, został skierowany przez biskupa Stanisława Zdzitowieckiego na dalsze studia do Leuven w Belgii ${ }^{7}$. Uzyskawszy tam stopień doktora filozofii, powrócił do kraju, by w 1908 r. objąć stano-

\footnotetext{
${ }^{5}$ Tak stało się np. w odniesieniu do biogramu np. ks. prof. Henryka Insadowskiego, gdzie wiele faktów udało się zrekonstruować na podstawie pozostawionych przezeń dokumentów o charakterze prywatnym (notatki, korespondencja). Por. Jońca 2020, 28594. Materiały, jakie pozostały po ks. prof. A. Szymańskim, wydają się wszelako cenniejsze, gdyż mają one charakter naukowy, a nie biograficzny.

${ }^{6}$ Świadczy o tym chociażby powołanie się autora na publikację prof. Czesława Martyniaka pt. „Moc obowiązująca prawa a teoria Kelsena”, wydaną w 1938 r. BU KUL, Rkps, k. 13.

${ }^{7}$ Zob. także Karolewicz 1981, 219.
} 
wisko profesora filozofii w cieszącym się znakomitą renomą Diecezjalnym Seminarium Duchownym we Włocławku. Tam rozwijał swoją działalność naukową i publicystyczną, a także dydaktyczną. Prowadził wykłady m.in. z logiki, pedagogiki i dydaktyki, a także z ogólnych zagadnień prawa cywilnego. W działalności naukowej skupiał się na zagadnieniach społecznych, historycznych i społeczno-ekonomicznych. Najważniejszym dziełem włocławskiego okresu jego działalności naukowej była praca pt. „Zagadnienie społeczne", w której przedstawił oryginalną syntezę społecznej nauki Kościoła. Opracowanie to zyskało sobie wielką popularność i przez wiele lat służyło jako podręcznik wykorzystywany w polskich seminariach duchownych. Był także „redaktorem odpowiedzialnym” czasopisma teologicznego pt. „Ateneum Kapłańskie”. W periodyku tym wiele miejsca poświęcano naukom społecznym (do najaktywniejszych autorów należał ks. prof. A. Szymański).

W 1918 r. z inicjatywy ks. prof. Idziego Radziszewskiego ${ }^{10}$ powstał w Lublinie Katolicki Uniwersytet Lubelski ${ }^{11}$. Wykłady z polityki społecznej i historii katolicyzmu objął na nim ks. prof. A. Szymański, który pierwszego rektora lubelskiej wszechnicy dobrze znał z Leuven. Obok pracy dydaktycznej w nowym miejscu młody uczony nadal rozwijał się naukowo. W 1919 r. habilitował się na Uniwersytecie Jagiellońskim, a w 1924 r. otrzymał tytuł profesora zwyczajnego. KUL szybko zauważył i docenił jego potencjał. W 1920 r. został dziekanem Wydziału Prawa Kanonicznego, a w 1931 r. objął funkcję dziekana Wydziału Prawa i Nauk Społeczno-Ekonomicznych. W 1933 r. został wybrany rektorem Katolickiego Uniwersytetu Lubelskiego.

${ }^{8} \mathrm{O}$ pracy tej po latach prymas Stefan Wyszyński napisał: „od kiedy Antoni Szymański wydał swoje «Zagadnienie społeczne», dało się odczuć, że katolicka nauka społeczna w Polsce wchodzi na drogę systematyzacji. Dotychczas bowiem musiała ona walczyć o miejsce w zespole nauk teologicznych i moralnych, głównie metodą polemiki publicystycznej”; cyt. za: Nitecki 2008, 68. Zob. także Fudali 1993, 21. Uwagi na temat osobistych relacji pomiędzy oboma kapłanami zob. Raina 1979, 71.

${ }^{9}$ Rzeczona „odpowiedzialność” w tytule jego funkcji znaczyła, że jest on odpowiedzialny za czasopismo przed władzami. Dalsze uwagi: Wrona 2005, 141. O piśmie z wielkim szacunkiem wypowiadał się m.in. prymas Stefan Wyszyński. Por. Wyszyński 2002,63 .

${ }^{10}$ Wybrane biogramy ks. Idziego Radziszewskiego zob. Wojtkowski 1948; Karolewicz 2000; Kremer 1922.

${ }^{11}$ Szerzej o powstaniu KUL zob.: Byzdra-Kusz 2019. 
Niezależnie od powyższego Ksiądz Profesor czynnie uczestniczył w życiu publicznym. Brał udział w pracach Rady Społecznej przy Prymasie Polski, współtworzył Związek Polskiej Inteligencji Katolickiej [Walewander 2000, 63] i Towarzystwo Wiedzy Chrześcijańskiej. Za zasługi został odznaczony Krzyżem Komandorskim Orderu Odrodzenia Polski.

W początkowym okresie okupacji jako rektor KUL ks. Szymański udostępnił budynki uniwersytetu dla potrzebujących schronienia uchodźców. Mimo tragicznych okoliczności podjął również decyzję o dalszym realizowaniu misji uniwersytetu. Uczelnia ta jako jedyna w Polsce rozpoczęła rok akademicki 1939/1940. W listopadzie 1939 r. jej rektor został aresztowany. Po wypuszczeniu przebywał w areszcie domowym. Odzyskawszy wolność, zdecydował się na pozostanie w ukryciu. Przebywał w podlubelskich Bełżycach, skąd kierował uniwersytetem. Prowadził tajne nauczanie ${ }^{12}$ oraz kontynuował działalność duszpasterską i organizacyjną. 9 października 1942 r. nieoczekiwanie zmarł na chorobę serca [Wilczyński 1962].

Prof. Szymański był twórcą lubelskiej szkoły społecznej nauki Kościoła [Ziółek 1997, 107]. Odznaczył się na niwie naukowej, dydaktycznej i organizacyjnej. Opublikował 238 rozpraw i artykułów z zakresu filozofii, etyki, socjologii oraz ekonomii. W ostatniej dekadzie życia wydał m.in. „Kodeks społeczny”, „Ekonomikę i etykę” oraz opracował kolejne, trzecie już wydanie „Zagadnienia społecznego”. Prezentował swoje krytyczne argumenty wobec ówczesnych założeń kapitalizmu i socjalizmu. Swoje poglądy opierał na europejskiej myśli społecznej nauki Kościoła. Jego dorobek naukowy stanowi fundamentalny wkład do polskiej doktryny katolickiej nauki społecznej ${ }^{13}$.

\section{WYBRANE POGLĄDY \\ KS. PROF. ANTONIEGO SZYMAŃSKIEGO NA PRAWO}

W skrypcie zatytułowanym „Prawo” przechowywanym przez Bibliotekę Uniwersytecką KUL ks. prof. A. Szymański daje szczegółowy wykład filozofii prawa. Uwagę zwraca zdumiewająca wnikliwość autora i jego znajo-

\footnotetext{
${ }^{12}$ Uwagi na temat tajnego nauczania prowadzonego dla studentów prawa KUL zob. Jońca 2015, 130-33.

${ }^{13}$ Dalsze uwagi na temat życiorysu i osiągnięć ks. prof. A. Szymańskiego zob. Strzeszewski 1949, 1-10; Bogusz 1985, 279-94; Pawlak 2011, 209-23; Goliński 1946; Fel i Wódka 1962.
} 
mość wiodących ówcześnie stanowisk filozoficznoprawnych. W pracy tej powoływane są przede wszystkim poglądy Hansa Kelsena ${ }^{14}$, ale można spotkać w niej również erudycyjne odesłania do myśli Rudolfa von Jheringa, Georga Jellinka, Herberta Harta czy Léona Duguita. Ponadto Szymański licznie korzysta z dzieł filozofów, m.in. św. Tomasza z Akwinu, Tomasza Hobbesa i Jana Jakuba Rousseau.

Już na wstępie autor ujawnia prawonaturalistyczny charakter swoich przekonań. Znamienne dla okresu, w którym ks. A. Szymański spisywał swoje refleksje, jest przejęcie się kwestią tzw. legalnej bezprawności, o której tuż po II wojnie światowej pisał m.in. Gustaw Radbruch [Radbruch 2000, 256-66]. W tym duchu prof. Szymański pisze: „Prawo, które nie spełnia tych zadań, ma tylko pozory prawa, ale nie jest prawem, gdyż jest sprzeczne $\mathrm{z}$ dobrem powszechnym, wtedy jest bezprawiem, nadużyciem funkcji zbiorowego życia. Dobro powszechne jest przedmiotem i bezpośrednim celem prawa, ale oczywiście służy dobru ludzi, bo dobro powszechne to dobro ludzi żyjących w społeczeństwie"15.

Swoje wywody autor rozpoczyna od przedstawienia znaczeń terminu prawo. Trafnie wskazuje na wieloznaczność tego terminu. W celu właściwego wyeksplikowania jego znaczenia, odwołuje się do myśli średniowiecznych filozofów (szczególnie do nauczania św. Tomasza z Akwinu). Uznanie dla twórczości Akwinaty wyraża m.in. powołując się na zaskakujące wyznanie Rudolfa von Jheringa. Szymański podkreśla, że filozof ten: „przygotowując nowe wydanie swej pracy Zweck im Recht [Jhering 1887, 250-55] zapoznawszy się z filozofią prawa św. Tomasza z Akwinu, nie wahał się wyznać, że gdyby znał tę filozofię wcześniej, prawdopodobnie nie napisałby swej pracy, gdyż jej główne tezy są gruntownie i jasno wyłożone przez tego myśliciela średniowiecznego"16.

Dalej przedstawia autor typowo teoretycznoprawny wykład o ogólnych zagadnieniach prawoznawstwa. Zajmuje klarowne stanowisko odnoszące się do obowiązku prawodawcy polegającym na należytym ogłoszeniu prawa.

\footnotetext{
${ }^{14}$ Wiele uwagi rozbiorowi i krytyce poglądów niemieckiego uczonego poświęcił również Czesław Martyniak, którego myśl bez wątpienia miała wpływ na poglądy ks. Szymańskiego, zob. Stochmal 2020, 97-118.

${ }^{15}$ BU KUL, Rkps 2277, k. 11. Odkryte notatki w istotny sposób uzupełniają ustalenia Olgi Ostaszewskiej oraz Kazimierza Ostaszewskiego. Autorzy ci poświęcili krótki wywód na temat poglądów ks. Szymańskiego na totalitaryzm. Z omawianego źródła jednak nie korzystali, zob. Ostaszewska i Ostaszewski 2011, 512-13.

${ }^{16}$ BU KUL, Rkps 2277, k. 2.
} 
Pisze: „Postanowienie rozumu staje się prawem, gdy jest ogłoszone, tj. ujawnione wobec podporządkowanych prawu, a nie zachowane tylko w myśli prawodawcy, i podane im do wiadomości; należycie, zgodnie $\mathrm{z}$ naturą prawa, zwyczajowo lub sposobami ustalonymi przez prawo. Prawo nie ogłoszone należycie, nie obowiązuje" ${ }^{\prime 17}$.

Odnosi się on również do celu prawa, którym jest według niego dobro powszechne. Wynika to z natury człowieka, której charakter nakazuje mu żyć w społeczeństwie, bowiem tylko w takich warunkach możliwa jest jego przyrodzona egzystencja. „Człowiek jest jestestwem społecznym - argumentuje - żyje w warunkach społecznego życia i tylko w nich może osiągać cel swego życia. To współżycie wymaga ustalonego ładu i porządku, zgodnego z celem społeczności, czyli z dobrem powszechnym. Prawo ma na celu ustalenie swego porządku, określenie praw i obowiązków ludzi względem zbiorowości i wzajemnie między nimi oraz obowiązków zbiorowości względem ludzi, zależnie od wymagań dobra powszechnego"18.

Ksiądz Profesor przedstawia następnie swój pogląd na kwestię obowiązywania prawa. Wskazuje na temporalny aspekt tego zjawiska, podkreślając zarazem obiektywność wiążącego charakteru prawa w oderwaniu od osoby prawodawcy. Zauważa: „Będąc tworem rozumu i woli norma prawna jest psychicznym przeżyciem ze względu na sposób powstania. [...] Norma prawna ma pewną samoistność obowiązującą, obowiązuje nawet po śmierci prawodawcy lub po jego ustąpieniu z urzędu i niezależnie od uznania podwładnych"19. Ks. Szymański ujawnia przy tym dokładną znajomość najważniejszych stanowisk prezentowanych w ówczesnej filozofii prawa. Cytuje m.in. prof. Cz. Martyniaka, który o tym zagadnieniu pisał: „Raz utworzone prawo obiektywizuje się i jego moc obowiązująca ma charakter obiektywny. Jak prawda, wykryta przez rozum spekulatywny, odrywa się niejako od podmiotu, który ją odkrył i przeżył, tak prawo, ustanowione przez rozum praktyczny, uniezależnia się od podmiotu, który je sformułował i ustanowił" [Martyniak 1938, 154].

Neotomistyczne przekonania autora ujawniają się w stanowczym odcięciu się od koncepcji woluntarystycznego pojmowania prawa, którego zwolennicy postrzegali prawo wyłącznie jako akt woli prawodawcy. Swoje stanowisko w tej materii wyjaśnia Ksiądz Profesor następująco: „oczywiście

\footnotetext{
17 Tamże, k. 10.

18 Tamże, k. 11.

19 Tamże, k. 13.
} 
wola prawodawcy ma udział w tworzeniu prawa, ale znaczenie woli jest drugorzędne. Treść prawa, tj. ustalenie celu i środków, innemi słowy, ustalenie porządku życia społecznego nie zależy od woli, lecz od rozumu. Wola jedynie skłania umysł prawodawcy do działania, aby zajął się ustaleniem porządku współżycia oraz czuwał, aby ogłoszone przepisy prawa były zachowane" ${ }^{20}$.

Wiele wskazuje na to, że prof. Szymański intuicyjnie odróżniał pojęcie normy prawnej od przepisu prawnego. Utożsamia on bowiem w wielu miejscach normę z normą postępowania istniejącą obiektywnie i niezależnie $\mathrm{w}$ naturze i odróżnia ją od przepisu, który rozumie jako wyrażone przez prawodawcę sformułowanie zawierające w swej treści normę odkrytą przez przeżycie psychiczne rozumu. Antycypuje tym samym fundamentalne założenie ogłoszonej przez Z. Ziembińskiego koncepcji odróżnienia przepisu prawnego od normy prawnej [Ziembiński 1960]. Ten wybitny teoretyk prawa zauważył bowiem, że przepisy prawne, jako wyróżnione graficznie jednostki redakcyjne tekstów aktów prawnych, wyrażają generalne i abstrakcyjne normy postępowania. To odkrycie, wynikające z dogłębnie analitycznego badania struktury tekstów prawnych jest do dziś uważane za przełomowe w polskiej teorii prawa. Fakt choćby intuicyjnego pojmowania przez A. Szymańskiego tej gatunkowej różnicy pomiędzy przepisem prawnym a normą prawną wskazuje na szczególną wnikliwość badawczą lubelskiego uczonego.

\section{KS. PROF. ANTONI SZYMAŃSKI WOBEC POZYTYWISTÓW}

W dalszej części swej pracy kontynuuje ks. Szymański polemikę z przedstawicielami pozytywizmu prawniczego. Koncepcjom H. Harta i L. Duguita zarzuca niesłuszny rozdział prawa od moralności. Pisze on: „Teoria Harta odbiera całemu życiu powszechnemu charakter moralny, to co się dzieje w państwie, ze względu na posłuch prawodawcy i prawa jest pozamoralne i nie ma znaczenia dla moralnej wartości człowieka, bo te dotyczą tylko wewnętrznego życia ludzi. Jest to sprzeczne z poczuciem moralnym i z przymusem moralności a zarazem stanowi niesłychane niebezpieczeństwo dla

20 Tamże, k. 2. 
życia politycznego, zwłaszcza międzynarodowego"21. To założenie koncepcji prawa pozytywnego krytykuje $\mathrm{z}$ największą stanowczością w całej pracy. Formułuje znamienne dla tej polemiki zdanie: „bezprawie nie jest już bezprawiem, lecz legalnością"22.

Istotne wady w prezentowanych koncepcjach wytyka także innym pozytywistom. Krytykuje nowatorską jak na tamte czasy koncepcję normy podstawowej, sformułowaną przez normatywistę Hansa Kelsena [Kelsen 1934]. W prezentowanych poglądach zgadza się z ideami głoszonymi przez Cz. Martyniaka ${ }^{23}$. Zdaniem niemieckiego filozofa norma podstawowa miała być gwarantem obowiązywania systemu prawa, a tym samym legitymować obowiązywanie innych norm danego porządku prawnego. W odniesieniu do tej koncepcji A. Szymański zauważa: „Opieranie porządku prawnego na normie postulowanej podważa cały ten porządek, bo nie zapewnia pewności prawodawcy, nie stwarza w nim tego mocnego przekonania, że może wymagać posłuszeństwa dla przepisów prawa, ani dostatecznie nie przekonywa podwładnych, że powinni zachować prawo, nawet dla nich niewygodne i ciężkie. [...] Norma postulowana bowiem nie jest normą prawną"24.

W związku z powyższym, lubelski uczony stanowczo odtrąca krytykę wobec koncepcji prawa przyrodzonego manifestowaną przez Kelsena. Niemiecki uczony uważał, że prawo przyrodzone nie istnieje, bowiem jest ono tylko umysłowym wymysłem i w gruncie rzeczy jest prawem pozytywnym, a staje się nim przez konieczną konkretyzację prawa przyrodzonego. Bez tego zabiegu nie ma ono formy ani treści: „np. norma: pacta sunt servanda, należy dotrzymywać umów i zobowiązań, jest normą bez formy i treści. Staje się normą właściwą przez indywidualizację. Trzeba ją skonkretyzować zarówno co do osób, które są obowiązane, co do czasu trwania umowy, sposobu rozstrzygania sporów itd., jak i co do treści zobowiązania. Jedno zaś i drugie jest dziełem człowieka, a tym samym normą pozytywną"25. Ks. Szymański przyznaje wprawdzie, że ogólna, niezindywidualizowana norma przyrodzona wymaga skonkretyzowania, jednak odmawia trafności twierdzeniu, iż norma przyrodzona bez takiej konkretyzacji nie istnieje. Podnosi, że w podanym przykładzie bez umowy stron nie istnieje norma

\footnotetext{
21 Tamże, k. 62.

22 Tamże, k. 62.

${ }^{23}$ Zob. m.in.: Acker 1977, 5-13; Czepita 1980, 134-37; Łuszczyńska 2004, 151-64.

${ }^{24}$ BU KUL, Rkps 2277, k. 93.

${ }^{25}$ Tamże, k. 210.
} 
pacta sunt servanda, ponieważ: „Przeciwnie, normy szczegółowe pozytywne opierają się na tej normie ogólnej. To ona ją uszczegółowia i ją dostosowuje do konkretnych wypadków albo dokładniej do podciągnięcia tych wypadków pod jej zakres. Przeto przez taką konkretyzację prawo przyrodzone nie staje się prawem pozytywnym, ludzkim, pochodzącym od prawodawcy ludzkiego" 26 .

Nadto kontestuje on twierdzenie Kelsena i pozytywistów o tym, że prawo przyrodzone właściwie nie określa tego, co sprawiedliwe, bowiem normy ogólne nie zawierają treści, którą nadaje im dopiero prawodawca w drodze stanowienia lub sędzia w drodze stosowania. Ks. Szymański obnaża skrajność tego poglądu poddając dogłębnej analizie nakaz „czyń dobro, nie czyń złego". Jego zdaniem, przyjmując założenia prezentowane m.in. przez Kelsena, norma powyższa nie zawierałaby treści, bowiem najpierw trzeba byłoby określić, co jest dobrem, a co złem. Zadanie to, jak chciał Kelsen i jego zwolennicy, miałoby spoczywać na prawodawcy i sędziach. To oni tej ogólnej normie mieliby nadawać treść, a nie prawo przyrodzone. Ich władza sięgałaby więc tak daleko, że możliwe byłoby ukaranie za kradzież tego, kto nie ukradł. Wobec tego taka ogólna norma prawa przyrodzonego byłaby de facto normą prawa pozytywnego. Tego rodzaju interpretację A. Szymański w całości odrzuca. Wskazuje, że: „Teoria ta jest błędna i nie podważa istnienia prawa przyrodzonego. [...] W podanym przykładzie wyraz dobro, zło nie jest pustym bez treści wyrazem, lecz jest dobrem natury ludzkiej, branej jednostkowo lub społecznie, lub czymś złym dla niej. Właśnie dlatego, że prawo przyrodzone opiera się na naturze ludzkiej i związanym z nią porządkiem, dobro i zło posiada wyraźną treść. Podawana w skrócie norma brzmi właściwie: «Nie czyń tego, co jest sprzeczne $\mathrm{z}$ naturą ludzką jednostkową lub społeczną, czyń to, co z nią jest zgodne, w czym się wyraża człowieczeństwo». [...] Żeby wiedzieć przeto, co jest dobre a co złe, co sprawiedliwe a co niesprawiedliwe nie potrzeba pomocy prawodawcy ani sędziego; wystarczy zdrowy rozum. Jednakże wtedy, gdy chodzi o czynności bardziej skomplikowane, o stosunki bardziej złożone i trudne, potrzeba”27. Następnie wywodzi: „Jest to formuła błędna, gdyż ma oznaczać, że czynność jest dobra tylko dlatego, że jest nakazana (i odwracalnie, zła z tego powodu, iż jest zabroniona). Ani norma bowiem, ani kwalifikacja czyn-

\footnotetext{
26 Tamże, k. 212.

${ }^{27}$ Tamże, k. 214.
} 
ności pod względem moralnym i sprawiedliwym nie zależy od wolnego uznania prawodawcy, który przeciwnie, jest związany prawem przyrodzonym i nie może go zmieniać"28.

Wskazuje więc A. Szymański, że prawo pozytywne nie może istnieć bez prawa przyrodzonego, bowiem to z niego ono wynika i właśnie z niego czerpie ono wartości potrzebne do wypełnienia treści norm prawnych i uzasadnienia ich obowiązywania. Prawo przyrodzone jest więc konieczne jako swego rodzaju „podbudowa” dla prawa pozytywnego ${ }^{29}$. Prawo pozytywne stanowi zatem uzupełnienie prawa przyrodzonego, które wynika z natury ludzkiej, choć jest ono wcześniejsze od woli człowieka i jego rozumu. „Jest ono dane - czytamy w dalszym wywodzie - w przyrodzonym porządku niezależnie od tego, czy je człowiek wykryje, czy je realizuje w swoich wolnych czynnościach, czy nie. Istnieje ono, jak istnieją prawa przyrody, zanim je człowiek pozna i sformułuje albo nawet jak ich wcale nie pozna; elektryczność była, choć jej człowiek nie znał i nie umiał ująć ani nią zwracał na nią uwagi”30.

\section{WNIOSKI}

W omówionych wyżej wybranych refleksjach ks. A. Szymańskiego poświęconych prawu i jego istocie zwraca uwagę silne neotomistyczne osadzenie jego przekonań. Lubelski uczony wyraźnie odrzuca koncepcję normatywną prawa. Bardziej niż w samej literze prawa, jego obowiązywalność upatruje on w poczuciu społecznej sprawiedliwości i słuszności. Zakłada, że poczucie sprawiedliwości społecznej jest elementem konstytuującym prawo, ogniwem, bez którego prawo nie może istnieć. Źródło słuszności prawa widzi tymczasem w przyrodzonej moralności i w poczuciu godności człowieka, w charakterystycznej dla istoty ludzkiej zdolności do abstrakcyjnego rozumowania oraz w jego świadomości i indywidualności, nie zaś w samym fakcie dokonania przez prawodawcę liczącej się prawnie czynności ustanowienia przepisu prawnego. Tego rodzaju personalistyczne przekonania regularnie manifestowane są w całym wykładzie ks. A. Szymańskiego.

\footnotetext{
28 Tamże, k. 228.

29 Tamże, k. 98.

30 Tamże, k. 137.
} 
W przechowywanym w Bibliotece Uniwersyteckiej KUL rękopisie prof. Szymański daje szczegółowy wykład historii koncepcji prawa naturalnego. Jego wywód przedstawia szczegółowe założenia prawonaturalizmu wraz z oryginalnym komentarzem do jego najważniejszych tez. Wykład ten nie odbiega w treści i formie od referatów filozofów prawa. Gruntowana analiza stanowisk europejskich filozofów prawa sytuuje ten tekst wśród istotnych syntez filozoficznoprawnych, a atrakcyjność lektury bez wątpienia zwiększają przedstawione w nim oryginalne argumenty i erudycyjne polemiki.

Zestawiając konkurencyjne względem siebie koncepcje prawa, prawonaturalną i pozytywistyczną, ks. Szymański bez wahania opowiada się za tą pierwszą. Jego postawa nie jest oparta na założonej z góry słuszności określonego rodzaju teorii. Podejmuje bowiem merytoryczną debatę zarówno $\mathrm{z}$ tezami przychylnymi pozytywistycznej wizji prawa, jak i z tezami krytycznymi względem koncepcji prawonaturalnej.

Analiza wybranych wątków z niepublikowanego rękopisu A. Szymańskiego pt. „Prawo”, prowadzi do konkluzji, że poglądy lubelskiego uczonego powinny zapewniać mu ważne miejsce wśród grona prawonaturalistów okresu międzywojennego. Jakkolwiek on sam do tego nie pretendował, odkrycie pozostawionych przez niego zapisków pozwala dziś tak właśnie o nim sądzić.

\section{PIŚMIENNICTWO}

Acker van, Leonardo. 1977. „Zapomniana krytyka Kelsena.” Roczniki Nauk Społecznych 5:5-13.

Antoni Szymański. O sprawiedliwość społecznq. Wybór pism. 2018. Wyboru dokonała, wstępem i przypisami opatrzyła J. Potrzeszcz. Kraków: Ośrodek Myśli Politycznej.

Bogusz, Magdalena. 1985. „Poglądy społeczno-ustrojowe Antoniego Szymańskiego.” Annales Universitatis Mariae Curie-Skłodowska 19:279-94.

Byzdra-Kusz, Paulina. 2019. „Między wizją a rzeczywistością. Sto lat Katolickiego Uniwersytetu Lubelskiego." Annalecta 2:49-72.

Czepita, Stanisław. 1980. „Koncepcje teoretycznoprawne w Polsce międzywojennej.” Czasopismo Prawno-Historyczne 32, nr 2:134-37.

Fel, Stanisław, i Marek Wódka, red. 2013. Ksiadz Antoni Szymański (1881-1942). Rektor, uczony, działacz społeczny. Lublin: Wydawnictwo KUL.

Fudali, Irena. 1993. Myśl społeczna Stefana Wyszyńskiego - Prymasa Polski. Kielce: Oficyna Poligraficzna Apla. 
Gazda, Zbigniew. 1998. Historia nurtu katolickiego w polskiej myśli ekonomicznej okresu Drugiej Rzeczypospolitej 1918-1939. Kielce: WSP.

Goliński, Zdzisław. 1946. „Śp. ks. dr Antoni jako Szymański, rektor KUL (1881-1942).” Wiadomości Diecezji Lubelskiej 23:419-23.

Jhering, Rudolf. 1887. Der Zweck im recht. Leipzig: Breitkopf \& Härtel.

Jońca, Maciej. 2015. „Pod osłoną nocy i mgły. Uwagi na temat nauczania prawa rzymskiego na ziemiach polskich pod okupacją hitlerowską." W Noctes Iurisprudentiae. Scritti in onore di Jan Zabłocki, red. Piotr Niczyporuk, i Anna Tarwacka, 125-34. Białystok: Temida 2.

Jońca, Maciej. 2020. Prawo rzymskie. Mirabilia. Warszawa: Wydawnictwo C.H. Beck.

Karolewicz, Grażyna. 1981. „Lowańczycy wśród profesorów Katolickiego Uniwersytetu Lubelskiego w okresie międzywojennym.” Archiwa, Biblioteki i Muzea Kościelne 43:217-29.

Karolewicz, Grażyna. 2000. Ksiadz Idzi Radziszewski i jego dzieło - Katolicki Uniwersytet Lubelski. Lublin: Katolicki Uniwersytet Lubelski.

Kelsen, Hans. 1934. Reine Rechtslehre: Einleitung in die rechtswissenschaftliche Problematik. Leipzig: Deuticke.

Kępa, Mateusz. 2016. „Kapitalizm w poglądach politycznych i ekonomicznych ks. Antoniego Szymańskiego." Studenckie Prace Prawnicze, Administratywistyczne i Ekonomiczne 20:159-73.

Kremer, Piotr. 1922. Śp. Ks. Idzi Radziszewski, rektor i założyciel Uniwersytetu Katolickiego w Lublinie. Włocławek: Księgarnia Powszechna i Druk.

Łuszczyńska, Małgorzata. 2004. „Filozof prawa natury - Czesław Martyniak (w 65. rocznicę śmierci)." Studia Iuridica Lublinensia 4:151-64.

Martyniak, Czesław. 1938. Moc obowiqzujaca prawa a teoria Kelsena. Lublin: Towarzystwo Naukowe KUL.

Nitecki, Piotr. 2008. „Włocławskie dzieje ks. Stefana Wyszyńskiego 1917-1946.” Studia Prymasowskie 4:168-288.

Ostaszewska, Olga, i Kazimierz Ostaszewski. 2011. „Środowisko Katolickiego Uniwersytetu Lubelskiego wobec totalitaryzmów 1918-1989.” Studia nad Faszyzmem i Zbrodniami Hitlerowskimi 33:511-28.

Pawlak, Zdzisław. 2011. „Włocławski okres działalności naukowej ks. prof. Antoniego Szymańskiego.” Studia Włocławskie 13:209-23.

Radbruch, Gustaw. 2000. „Ustawowe bezprawie i ponadustawowe prawo.” W Zarys filozofii prawa, red. Maria Szyszkowska, 276-86. Białystok: Temida 2.

Raina, Peter. 1979. Stefan Wyszyński, Prymas Polski. T. 1. Londyn: Oficyna Poetów i Malarzy.

Stochmal, Mirosław. 2020. „Czesława Martyniaka krytyka normatywizmu Hansa Kelsena." Miscellanea Iuridico-Historica 19, nr 2:97-118.

Strzeszewski, Czesław. 1949. „Ś.p. ks. Antoni Szymański.” Roczniki Nauk Społecznych 1, nr 1:1-10.

Szczęsny, Marian. 2005. Personalistyczna filozofia społeczna Antoniego Szymańskiego. Olsztyn: Wydawnictwo Uniwersytetu Warmińsko-Mazurskiego. 
Walewander, Edward. 2000. Katolicka a liberalna myśl wychowawcza w Polsce w latach 1918-1939. Lublin: Wydawnictwo KUL.

Wilczyński, Tomasz. 1962. „Ostatnie lata życia ks. Antoniego Szymańskiego.” Zeszyty Naukowe KUL 5, nr 3:115-26.

Wojtkowski, Andrzej. 1948. „Ks. Idzi Radziszewski.” Roczniki Filozoficzne 1:228-49.

Wrona, Grażyna. 2005. Polskie czasopisma naukowe w latach 1918-1939. Kraków: Wydawnictwo Naukowe Akademii Pedagogicznej.

Wyszyński, Stefan. 2002. Kościót i media. Warszawa: Instytut Wydawniczy Pax.

Ziembiński, Zygmunt. 1960. „Przepis prawny a norma prawna.” Ruch Prawniczy, Ekonomiczny i Socjologiczny 1:105-22.

Ziółek, Jan. 1987. Kulturotwórcza rola Kościoła na przełomie XIX i XX wieku. Lublin: Wydawnictwo KUL.

\title{
Wybrane poglądy ks. prof. Antoniego Szymańskiego na prawo. Uwagi na marginesie niepublikowanego rękopisu z Biblioteki Uniwersyteckiej KUL
}

\begin{abstract}
Abstrakt
W Bibliotece Uniwersyteckiej KUL znajduje się niepublikowany rękopis ks. prof. Antoniego Szymańskiego pt. „Prawo”. Jego analiza pozwala stwierdzić, że uczony ten posiadał dogłębną znajomość zagadnień filozoficzno-prawnych. Autor daje w nim szczegółowy wykład z historii koncepcji prawa naturalnego. Przedstawia również szczegółowe założenia prawonaturalizmu wraz z oryginalnym komentarzem do jego najważniejszych tez. Wykład ten nie odbiega w treści i formie od referatów „profesjonalnych" filozofów prawa. W swoich refleksjach przyjmuje stanowisko neotomistyczne.
\end{abstract}

Słowa kluczowe: Antoni Szymański; filozofia prawa; teoria prawa; prawo naturalne; pozytywizm prawniczy

\section{Selected Views of Rev. Prof. Antoni Szymański on Law. Notes on the Margin of an Unpublished Manuscript from KUL University Library}

\begin{abstract}
In the University Library of the Catholic University of Lublin there is an unpublished manuscript of Rev. Prof. Antoni Szymański entitled "Prawo" ("Law"). Its analysis allows us to state that this scholar had a profound knowledge of philosophical and legal issues. The author gives in it a detailed lecture on the history of the concept of natural law. He also presents the detailed assumptions of legal-naturalism with an original commentary on its most important theses. This lecture does not differ in content and form from the papers of "professional" philosophers of law. In his reflections he adopts a neotomistic position.
\end{abstract}


Keywords: Antoni Szymański; philosophy of law; legal theory; natural law; legal positivism

Information about Author: PATRYK KUPIS, MA - Faculty of Law and Administration, University of Szczecin; correspondence address: ul. Narutowicza 17A, 70240 Szczecin, Poland; e-mail: patryk.kupis@usz.edu.pl; https://orcid.org/0000-00023044-3350 